\title{
KEJAYAAN PERADABAN ISLAM DALAM PERSPEKTIF ILMU PENGETAHUAN
}

\author{
Suwarno \\ Program Studi Pendidikan Sejarah FKIP Universitas Muhammadiyah Purwokerto, Email : \\ suwarnopurwokerto@gmail.com
}

\begin{abstract}
ABSTRAK
Artikel ini membahas kejayaan peradaban Islam yang ditinjau dari perspektif ilmu pengetahuan. Catatan sejarah menunjukkan bahwa peradaban Islam pernah mencapai kejayaan pada masa kerajaan Bani Abbasiyah yang berpusat di Baghdad Irak, kerajaan Bani Fatimiyah di Kairo Mesir, dan kerajaan Bani Umayyah di Cordova Spanyol. Salah satu indikator kejayaan peradaban Islam itu adalah indikator dalam bidang ilmu pengetahuan. Ada dua elemen utama kejayaan peradaban Islam dalam persektif ilmu pengetahuan, yakni tingginya aktivitas ilmiah dan kemajuan ilmu pengetahuan baik ilmu agama maupun ilmu umum. Aktivitas ilmiah yang dimaksud ialah penyusunan buku-buku ilmiah dan gerakan penerjemahan. Kemajuan ilmu pengetahuan dalam disiplin ilmu agama meliputi ilmu tafsir, hadits, kalam dan fiqh. Sementara kemajuan dalam ilmu umum mencakup filsafat, kedokteran, astronomi, matematika, dan geografi.
\end{abstract}

Kata Kunci: Kejayaan; Peradaban Islam; Aktivitas Ilmiah; Ilmu Pengetahuan; Kemajuan

\begin{abstract}
This article discusses the triumph of Islamic civilization from a scientific perspective. Historical records show that Islamic civilization had achieved glory during the Bani Abbasid empire centered in Baghdad Iraq, the Bani Fatimid kingdom in Cairo Egypt, and the Bani Umayyah kingdom in Cordova, Spain. One indicator of the triumph of Islamic civilization is an indicator in the field of science. There are two main elements of the triumph of Islamic civilization in the perspective of science, namely the high level of scientific activity and the advancement of science in both religious and general sciences. The intended scientific activity is the preparation of scientific books and the translation movement. The progress of science in the disciplines of religion includes the science of interpretation, hadith, kalam and figh. While advances in general science include philosophy, medicine, astronomy, mathematics, and geography.
\end{abstract}

Keywords: Glory; Islamic Civilization; Scientific Activity; Science; Progress 


\section{PENDAHULUAN}

Sejarah Islam, merujuk Harun Nasution (1985: 56 - 89), dapat dibagi periodisasinya dalam tiga periode. Pertama, periode klasik $(650-1250 \mathrm{M})$ yang dibagi lagi dalam dua masa, (1) masa Kemajuan I (650 - 1000 M). Pada masa ini Islam tumbuh dan berkembang mulai dari masa Khulafaurrasyidin dan Bani Umayyah hingga mencapai puncak kejayaan pada masa Bani Abbasiyah; (2) masa Disintegrasi ke arah perpecahan dan kemunduran peradaban Islam yang berlangsung pada kurun waktu tahun $1000-1250$.

Kedua, periode Pertengahan (1250 - $1800 \mathrm{M})$ yang mencakup dua masa: (1) masa Kemunduran I dan (2) masa tiga kerajaan besar. Masa kemunduran I dimulai sejak hancurnya kota Baghdad pada 1258 M sampai tahun 1500 M. Sementara masa tiga kerajaan besar meliputi: Utsmani di Turki, Safawi di Iran, dan Moghul di India. Masa ini dibagi lagi menjadi dua masa, Kemajuan II (1500 - 1700 M) dan masa Kemunduran II yang ditandai dengan hadirnya kolonialisme dan imperialisme Barat.

Ketiga, periode modern sejak 1800 hingga awal abad XXI sekarang. Periode ini merupakan periode kebangkitan dunia Islam dengan kebijakan modernisasi baik di Turki maupun di Mesir. Hasilnya, selain proses modernisasi (westernisasi), belakangan muncul gerakan pembaruan Islam modern (modernisme Islam) yang dipelopori oleh Sayyid Jamaluddin al Afghani dan Syeikh Muhammad Abduh di Mesir, Sayyid Ahmad Khan di anak benua India dan Nursi di Turki.

Dalam perspektif sosiologis, sejarah Islam telah mengalami tiga gelombang transformasi masyarakat. Gelombang I transformasi masyarakat Islam adalah kelahiran Islam yang dibawa oleh Nabi Muhammad (610 - 632 M) sebagai kekuatan yang mencerahkan dan mengeluarkan bangsa Arab dari keadaan jahiliyah menuju nilai-nilai Islam (kebenaran, keadilan, persamaan, persatuan, dan sebagainya). Salah satu faktor penting yang membuat dakwah Islam pada tahap kelahiran ini berhasil adalah kepribadian Nabi Muhammad saw. yang sangat terpuji dengan sifat jujur (shiddiq), dapat dipercaya (amanah), terbuka dalam menyampaikan kebenaran (tabligh) dan cerdas (fathonah). Dalam masa dakwah sekitar 22 tahun yang terbagi dalam periode Mekah (12 tahun) dan periode Madinah (10) tahun, Nabi Muhammad berhasil melakukan transformasi budaya dari alam pikiran Jahiliyyah menuju alam pikiran Islam. Nilai-nilai dasar Islam yang menjadi batu sendi bagi transformasi masyarakat tersebut ialah tauhid, kemerdekaan, persamaan, persaudaraan, persatuan dan keadilan (Amin, 1995: 42 - 43).

Gelombang II transformasi masyarakat Islam adalah pertumbuhan dan perkembangan agama Islam yang berlangsung selama masa Khulafaurrasyidin (632 - 
661 M) dan masa Bani Umayyah (661 - 750 M). Gelombang II ini telah membawa Islam sebagai kekuatan pembebas bangsa-bangsa di kawasan Timur Tengah dari penindasan imperium Byzantium dan Persia, serta tersebarnya nilai-nilai agama dan budaya Islam ke luar Jazirah Arab. Beberapa wilayah yang berhasil dibebaskan pada masa Khulafaurrasyidin, antara lain: Damaskus (635 M), Baitul Maqdis, Palestina, Mesopotamia, dan Babilonia (640 M), Mesir (641 M), seluruh wilayah Iran (642 M), dan Tripoli (646 M). Selanjutnya wilayah-wilayah yang berhasil dibebaskan pada masa Bani Umayyah ke arah barat, meliputi: seluruh Afrika Utara dari Maroko, Aljazair, dan Tunisia, Andalusia atau Spanyol pada tahun 711 M. Sementara ke arah timur, Bani Umayyah berhasil membebaskan wilayah-wilayah di kawasan Asia Tengah seperti Uzbekistan, Turkistan, Afghanistan dan India bagian barat (wilayah Sind) (Amin, 1995: $44-45)$.

Selanjutnya, gelombang III transformasi masyarakat Islam ditandai dengan berkembangnya peradaban Islam mencapai masa puncak kejayaan. Gelombang ketiga ini terjadi pada masa Khilafah Bani Abbasiyah di Baghdad, Bani Fatimiyah di Kairo, dan Bani Umayyah di Andalusia (Spanyol).

Artikel ini berusaha untuk mengungkap kejayaan peradaban Islam dalam perspektif ilmu pengetahuan, khususnya pada masa Khilafah Bani Abbasiyah. Setelah dibuka dengan pendahuluan, artikel ini mengkaji dalam pembahasan indikator kejayaan peradaban Islam dan kejayaan peradaban Islam dalam perspektif ilmu pengetahuan. Kemudian artikel ini diakhiri dengan penutup.

\section{PEMBAHASAN}

\section{Indikator Kejayaan Peradaban Islam}

Terdapat enam data sejarah sebagai indikator kunci yang menunjukan kejayaan paradaban Islam pada masa Bani Abbasiyah, Bani Fatimiyah, dan Bani Umayyah di Andalusia (Amin, 1995: 47 - 50). Pertama, gerakan penerjemahan buku-buku ilmu pengetahuan (sains), sastra dan filsafat dari beberapa bahasa seperti Yunani, Mesir, Persia dan India ke dalam bahasa Arab.

Kedua, kemajuan di bidang filsafat yang ditandai oleh lahirnya para filsuf Muslim seperti Al Farabi (870-950 M), Ibnu Sina (980-1037 M), dan Al Ghazali (wafat 1111 M). Menurut Phillip K. Hitti, sumbangan terpenting peradaban Arab dan Islam di bidang filsafat kepada dunia adalah usaha peradaban Arab dan Islam dalam menyelaraskan alam pikiran Yunani dengan buah pikiran Islam. Ketiga, lahirnya pusat-pusat keilmuan Islam seperti Baghdad (Irak), Kairo (Mesir), dan Cordova (Andalusia/Spanyol). Keempat, berkembangnya disiplin-disiplin keilmuan baik ilmu-ilmu kealaman (sains), kemasyarakatan (sosial dan humaniora), maupun 
ilmu-ilmu keagamaan. Kelima, berkembang-nya seni bangunan (arsitektur) yang indah dan megah. Keenam, aktivitas perekonomian berkembang pesat baik pertanian, perdagangan maupun industri (Amin, 1995: 49 - 50).

Masa Khilafah Bani Abbasiyah yang lama (750 - $1258 \mathrm{M})$, para khalifah terbesarnya justru berada pada awal perkembangan Bani Abbasiyah, terutama pada sosok Khalifah Harun Al Rasyid (786 - 809 M) dan Al Makmun (813 - 833 M). Pada masa kedua khalifah inilah Bani Abbasiyah pada khusunya dan Dunia Islam pada umumnya mencapai puncak kejayaan peradaban Islam.

Pada masa Harun Al Rasyid, negara dalam keadaan makmur, kekayaan. melimpah ruah, keamanan terjamin, tidak ada pemberontakan dan wilayah kekuasaan yang luas tergelar dari Afrika utara hingga India. Disamping itu, pada masa Harun Al Rasyid hidup para filsuf, pujangga, seniman, pembaca Al Quran dan para ahli agama Islam. Merekalah yang menjadi tulang punggung dalam mengembangkan peradaban Islam hingga mencapai puncaknya (Mufrodi, 1997: 102).

Sultan Harun Al Rasyid mendirikan Perpustakaan Baytul Hikmah. Perpustakaan ini menjadi pusat perkembangan ilmu pengetahuan. Sebagai tempat untuk membaca, menulis, dan berdiskusi. Harun Al Rasyid sendiri memberikan keteladanan sebagai seorang pemimpin yang taat beragama, menunaikan ibadah haji setiap tahun bersama keluarga, para pejabat negara dan ulama, serta dikenal sangat dermawan kepada kaum fakir miskin (Mufrodi, 1997: 102).

Sultan Harun Al Rasyid merupakan penguasa terkuat pada waktu itu. Tidak ada penguasa di tempat lain yang wilayah kekuasaannya menjangkau dari ujung barat Afrika Utara hingga India di ujung bagian timur. Selain wilayah kekuasaan yang luas, ketinggian kebudayaan dan peradaban Islam Kekhalifahan Abbasiyah pada masanya tidak ada yang mampu menyamainya. Baghdad sebagai ibukota Abbasiyah tidak ada bandingannya dengan kota lain, termasuk dengan Konstantinopel ibukota Byzantium (Mufrodi, 1997: 103)..

Dibawah kepemimpinan Al Makmun, putra Harun Al Rasyid, peradaban Islam, terutama ilmu pengetahuan berkembang pesat, baik ilmu agama (Al Quran, Qiraat, Hadits, Fiqh, Kalam) maupun ilmu umum (bahasa, sastra, filsafat, sejarah, sains alam seperti geografi, matematika, kimia, dan biologi). Al Makmun mendirikan Perpustakaan Darul Hikmah sebagai pusat kajian keilmuan, dan membayar mahal para penerjemah. Aliran Muktazilah yang rasional ditetapkannya sebagai mazhab resmi negara. Kepribadian Khalifah Al Makmun, seorang yang haus dan pecinta ilmu pengetahuan telah mendorong berkembangnya berbagai aspek ilmu pengetahuan baik umum maupun keagamaan Islam (Faqih dan Munthoha, editor, 1998: 40). 
Strategi yang ditempuh oleh para Khalifah Bani Abbasiyah yang awal hingga berhasil mengembangkan peradaban Islam sampai puncak adalah dengan menerapkan tiga strategi. Pertama, keterbukaan dalam berbagai bidang, tidak hanya dalam aspek pengetahuan dan kebudayaan tetapi juga di bidang pemerintahan. Kedua, kecintaan pada ilmu pengetahuan, terutama sangat tampak pada diri Khalifah Al Makmun. Ketiga, toleran dan akomodatif dalam aspek kebudayaan. Banyak orang dari keluarga Bani Abbasiyah yang meniru kebudayaan Persia karena kebudayaan Persia sangat maju dan menghegemoni istana Abbasiyah (Mugiyono dalam Jurnal JIA, Vol, XIV, Nomor 1, Juni 2013, hlm. 6).

Namun sebenarnya pengaruh kebudayaan Persia terhadap peradaban Islam, mengutip Ahmed (1992: 4), hanya terbatas di bidang kesenian dan kesusasteraan yang diwarnai oleh corak mistisisme. Sementara itu, kebudayaan India juga berpengaruh terhadap peradaban Islam dalam lapangan astronomi, matematika, dan sistem desimal.

\section{Kejayaan Peradaban Islam dalam Persektif Ilmu Pengetahuan}

Elemen utama peradaban Islam ketika mencapai puncak kejayaannya adalah : (1) adanya aktivitas ilmiah, dan (2) kemajuan ilmu pengetahuan baik umum maupun keagamaan. Mengenai elemen pertama, aktivitas ilmiah ditandai dengan penyusunan buku-buku ilmiah, yang menurut Ahmad Syalabi (dalam Faqih dan Munthoha, 1998: 38), melalui 3 fase: pencatatan pemikiran/hadits/hal lain pada kertas kemudian dirangkap, pembukuan pemikiran/hadits/hal lain dalam satu buku tertentu, dan penyusunan serta pengaturan kembali buku-buku ke dalam pasal-pasal/bab-bab tertentu.

Aktivitas ilmiah selanjutnya adalah pensyarahan (penjelasan) dan pentahqiqan (editing) sampai pada kritik yang menghasilkan teori baru. Contoh: Muhammad bin Musa al Khawarizmi yang berhasil memisahkan aljabar dari ilmu hisab sehingga aljabar menjadi ilmu tersendiri (Faqih dan Munthoha, 1998: 42).

Selain penyusunan buku-buku ilmiah, aktivitas ilmiah berikutnya yang sangat penting dan mendorong kemajuan peradaban Islam hingga mencapai puncak kejayaan adalah penerjemahan. Aktivitas penerjemahan memiliki peranan yang sangat penting sebagai pembuka kejayaan peradaban Islam. Melalui penerjemahan, ilmu pengetahuan dari berbagai bahasa, terutama bahasa Yunani, Persia dan India ditransfer ke dalam bahasa Arab. Salah seorang penerjemah yang tersohor adalah Muhammad bin Ibrahim al Fasasi (ahli falak pertama) yang ditugaskan oleh Khalifah al Mansur menerjemahkan buku Sindahind, berisi ilmu falak dari India ke dalam bahasa Arab (Faqih dan Munthoha, 1998: 39). 
Pada masa Sultan Harun al Rasyid, aktivitas penerjemahan sangat intensif dalam menerjemahkan buku-buku ilmu pengetahuan dari bahasa Yunani. Namun penerjemahan dari bahasa Yunani tersebut tidak langsung ke bahasa Arab, tetapi diterjemahkan terlebih dahulu ke dalam bahasa Siriac. Aktivitas penerjemahan mencapai puncak pada masa Khalifah al Makmun. Melalui Perpustakaan Darul Hikmah, Al Makmun mengintruksikan kepada kepalanya, Hunain bin Ishaq, untuk menerjemahkan buku-buku dari bahasa Yunani ke dalam bahasa Arab. Hasil karya terjemahan Hunain bin Ishaq, seorang Kristen ahli bahasa Arab dan Yunani, adalah buku-buku karangan Euclide, Galen, Hipocrates, Appolonius, Plato, Aristoteles, Themitius, Paulus al Agini, dan Kitab Perjanjian Lama (Faqih dan Munthoha, 1998: 40).

Watt (1990: 139) menyebut Hunain ibn Ishaq (809 - 873) sebagai penerjemah paling terkemuka yang menerjemahkan karya-karya ilmiah berbahasa Yunani ke dalam bahasa Arab. Sebelum menerjemahkan buku-buku berbahasa Yunani, Hunain ibn Ishaq terlebih dahulu mengumpulkan manuskrip buku-buku yang akan diterjemahkannya.

Mengenai pentingnya gerakan penerjemahan bagi kejayaan peradaban Islam, Myers (2003: x) menunjukkan bahwa gerakan penerjemahan memainkan peranan utama. Aktivitas penerjemahan telah memungkinakan suatu kebudayaan dapat mempelajari kebudayaan lainnya. Hasil yang didapatkan dari aktivitas dan gerakan penerjemahan lebih menakjubkan ketimbang kemenangan dan kekuasaan atas wilayah lain melalui jalur militer.

Aktivitas penerjemahan karya-karya ilmiah dari bahasa Yunani ke dalam bahasa Arab pada gilirannya kemudian telah mendorong berkembangnya berbagai disiplin ilmu pengetahuan di kalangan kaum muslim, terutama filsafat, matematika, astronomi, geografi dan ilmu-ilmu kealaman. Dari berbagai disiplin ilmu pengetahuan tersebut, filsafat dapat dipandang sebagai ilmu yang paling penting karena filsafat merupakan "induknya ilmu pengetahuan." Filsafat menjadi pusat perhatian di kalangan para ilmuwan muslim (Bilgrami dan Sayid Ali Asyraf, 1989: 17).

Merujuk pendapat Akbar S. Ahmed, ada tiga arus kebudayaan kuno yang mempengaruhi arah perkembangan ilmu pengetahuan di dunia Islam ketika peradaban Islam bergerak menuju puncaknya. Arus silang budaya itu terjadi melalui aktivitas penerjemahan dari tiga bahasa: Yunani, Persia dan India. Kebudayaan Yunani yang disebut Hellenisme dan mempengaruhi perkembangan ilmu pengetahuan dalam peradaban Islam adalah dalam bidang filsafat dan kedokteran. Beberapa filsuf yang karyanya berpengaruh di Dunia Islam ialah Plato, Aristotels, Euclide, dan 
Neo-platonic. Dari bidang kedokteran yang paling berpengaruh adalah karya Hippocrates dan Galen (Ahmed, 1992: 49).

Pada akhirnya, sekitar awal abad ke-12, melalui karya Al Ghazali, pemikiran-pemikiran Yunani dapat diterima dan masuk ke dalam arus utama peradaban Islam. Selain itu, terdapat arus samping untuk mengkaji secara intensif filsafat dan sains Yunani (Watt, 1990: 140). Dalam perkembangannya kemudian, filsafat dan sains Yunani sudah diolah dan dikembangkan oleh para filsuf dan ilmuwan sebagai bagian dari peradaban Islam.

Elemen kedua kejayaan peradaban Islam setelah aktivitas ilmiah adalah kemajuan dalam bidang ilmu pengetahuan, baik ilmu agama maupun ilmu umum. Kemajuan dalam ilmu agama, terutama meliputi ilmu tafsir, ilmu hadits, ilmu kalam dan ilmu fikih. Ilmu tafsir mengalami perkembangan pesat lewat penafsiran secara sistematis dan terpisah dari Hadits. Ahli tafsir pertama adalah Al Farra. Baik aliran Ahlussunnah, Syiah maupun Mu'tazilah telah memiliki ahli tafsir masing-masing (Faqih dan Munthoha, 1998: 43).

Perkembangan ilmu hadits mencapai puncaknya, yang ditandai dengan munculnya Al Kutub Al Sitah dari 6 ahli hadits, yakni: Bukhari, Muslim. Ibnu Majah, Abu Dawud, Al Tirmidzi dan Al Nasai. Sementara ilmu kalam berkembang dari adanya dorongan untuk membela Islam dengan pemikiran filsafat dari serangan orang-orang Kristen dan Yahudi. Para ahli ilmu kalam datang baik dari aliran Mu'tazilah maupun Ahlu Sunnah. Dari aliran Mu'tazilah, mereka antara lain: Al Allaf, Al Nizam, Al Jahiz, Al Jubbai, dan Abu Hasyim. Sebaliknya dari kalangan Ahlussunnah, al: Al Asy'ari, Al Baqillani, Al Juwaini, Al Ghazali, dan Maturidi (Faqih dan Munthoha, 1998: 44 - 46).

Berikutnya, ilmu fikih telah berkembang sejak zaman Abbasiyah awal dengan terbentuknya empat mazhab fikih. Yang pertama mazhab Hanafi yang didirikan oleh Imam Abu Hanifah, kedua mazhab Maliki dengan pendiri Imam Malik, mazhab Syafii yang didirikan oleh Imam Asy Syafii, dan mazhab Hanbali dengan pendirinya Imam Abu Hanifah. Mereka merupakan ulama ahli fikih terbesar yang diakui oleh Dunia Muslim Ahlu Sunnah hingga sekarang (Faqih dan Munthoha, 1998: 46).

Menurut W. Montgomery Watt, terciptanya empat mazhab fikih Ahlussunnah, yakni Hanafi, Maliki, Asy-Syafii dan Hanbali terbentuk pada abad pertama khilafah Abbasiyah. Hal itu dibuktikan dari hadirnya kitab kumpulan fikih dan hadits karangan para pendiri mazhab tersebut atau dari para murid utamanya. Dengan adanya kumpulan kitab fikih dan hadits empat mazhab tersebut telah menjadi landasan bagi peradaban Islam beserta kehidupan intelektualnya (Watt, 1990: 134). 
Selanjutnya, kemajuan dalam bidang ilmu umum, terutama dalam ilmu filsafat, kedokteran, atronomi, matematika, dan geografi. Dalam ilmu filsafat, para filsuf yang ternama, antara lain: Ya'qub bin Ishaq al Kindi, Abu Nasr al Farabi, Ibnu Sina, Ibnu Bajah, Ibnu Thufail, Al Ghazali, dan Ibnu Rusyd (Faqih dan Munthoha, 1998: 48). Dalam bidang kedokteran, peradaban Islam telah memunculkan banyak dokter terkenal, al: Yuhanna bin Musawaih, Abu Bakar al Razi, Ibnu Sina, Ibnu Maimun, Abu al Qasim, Hunain ibnu Ishaq, Tsabit bin Qurrah, dan Qistha ibnu Luqba (Faqih dan Munthoha, 1998: 48). Dalam ilmu astronomi, beberapa astronom yang terkenal, al: Al Fazzari, Al Farghani, Al Balkhi, Al Khawarizmi, Al Battani, Abu Hasan Ali dan Al Biruni. Sementara untuk bidang ilmu matematika, Al Fazzari yang mengenalkan sistem angka arab dan angka nol, Al Khawarizmi mengembangkan tabel angka-angka, berhitung dan aljabar, Umar Khayyam, ibnu Tsabit (Faqih dan Munthoha, 1998: 49 $50)$.

Selanjutnya dalam bidang geografi, pada masa Harun Al Rasyid, kaum muslim telah melawat sampai Asia selatan, tenggara dan timur, Afrika dan Eropa. Ahli geografi yang ternama, al: Ibnu Khardazabah, Ibnu al Haik, Ibnu Fadhlan, Al Muqaddasy, dan lain sebagainya (Faqih dan Munthoha, 1998: 50).

Beberapa ilmuwan muslim dari zaman kejayaan peradaban Islam yang paling tersohor dan dipandang berpengaruh besar di Barat adalah Al Kindi, Al Razi, Al Farabi, Ibnu Sina, Al Ghazali, dan Ibnu Rusyd. Al Kindi (wafat tahun 873 M), merupakan filsuf pertama dan satu-satunya yang berasal dari keturunan Arab. Al Kindi adalah seorang ilmuwan serba bisa yang karyanya bersifat ensiklopedis meliputi bidang matematika, astrologi, kedokteran, fisika, farmasi, geografi, musik dan penggunaan bilangan Hindu. Dua karyanya tentang geometri dan otik fisiologis dipakai sebagai rujukan oleh Roger Bacon dan Witelo (Myers, 2003: 1).

Abu Bakar Al Razi (864 - 925), seorang ilmuwan yang mengabdikan dirinya dalam penelitian bidang pengobatan atau kedokteran yang dilakukannya di kota Baghdad. Karya utama Al Razi adalah ensiklopedi obat-obatan yang berjudul Al Hawi, buku studi perbandingan pengobatan. Karya Al Razi tersebut diterjemahkan oleh Farragut ke dalam bahasa Latin dengan judul Continens. Dalam buku tersebut, Al Razi membandingkan pengobatan dari bangsa Yunani, Persia, India dan Arab (Ahmed, 1992: 49 - 50). Ungkapan-ungkapan yang berasal dari Al Razi seperti kerjasama (cooperation), saling tolong menolong secara menguntungkan (mutual help), dan saling membantu secara menguntungkan (mutual assistance) dibangkitkan lagi oleh Petr Kropotkin melalui karyanya, Mutual Aid (1902). Menurut Myers (2003: 5), karya Petr Kropotkin yang berisi pemikiran Al Razi dijadikan sebagai bantahan atas pemikiran teori Darwin mengenai survival of the fittest. Jika para Darwinis menganggap survival 
of the fittest sebagai hukum alam yang mendasar, Petr Kropotkin mengunggah kembali pemikiran Al Razi, mutual aid sebagai hukum alam yang fundamental.

Abu Nasr Al Farabi (wafat tahun 950 M) adalah ilmuwan muslim keturunan Turki. Al Farabi dikenal sebagai filsuf yang mengembangkan pengetahuan dan logika sebagai bagian dari filsafat. Karyanya yang paling berpengaruh adalah buku berjudul Ideal State (Negara Ideal). Dalam buku tersebut, Al Farabi berusaha mengislamkan pemikiran lato dalam karyanya Republic (Ahmed, 1992: 50). Jika Plato menganggap negara ideal ketika pemimpin atau rajanya adalah seorang filsuf, maka Al Farabi melihat negara ideal bilamana yang menjadi pemimpinnya adalah seorang nabi.

Abu Ali ibnu Sina (980 - 1037) yang berasal dari Bukhara dipandang sebagai "bintang dari para ilmuwan." Ibnu Sina dikenal sebagai ilmuwan yang banyak berkecimpung dalam bidang filsafat dan kedokteran. Karya monumentalnya, Canon of Medicine, telah diterjemahkan ke dalam bahasa Latin dan dipergunakan di Eropa hingga abad ke-16 (Ahmed, 1992: 50).

Ibnu Sina yang di Barat disebut Avicena, terkenal dengan 60 karyanya dalam berbagai bidang, tidak hanya ahli dalam bidang filsafat dan kedokteran, tetapi juga geometri, astronomi, teologi dan seni. Dalam karya yang berjudul Ktab al Shafa, Ibnu Sina membagi pengetahuan menjadi dua, praktis dan teoretis. Pengetahuan praktis meliputi etika, ekonomi dan politik, sementara pengetahuan teoretis mencakup fisika, matematika dan metafisika (Myers, 2003: 37). Dalam hal kedokteran, Ibnu Sina adalah ilmuwan muslim yang berhasil mengumpulkan seluruh pengetahuan ilmu faal, anatomi dan intervensi medis dari Yunani, Persia dan India sejak zaman Hippocrates dan Galen serta digabungkannya dengan riset yang dilakukannya sendiri. Sangat pantas bila Avicenna diberi gelar sebagai "Bapak Kedokteran Modern" (Faisal Aslim dalam https://www.zenius.net, hlm. 5).

Abu Hamid Al Ghazali (1058 - 1111) dikenal sebagai ilmuwan muslim yang berhasil memadukan pemikiran muslim ortodoks dengan pemikiran sufi yang banyak dipengaruhi oleh pengetahuan Hellenistik. Karya monumentalnya berjudul Ihya Ulumuddin, sangat dihargai sebagai karya ilmiah keagamaan yang bermutu tinggi. Anne Marie Schimmel menjuluki Al Ghazali sebagai "muslim terbesar setelah Nabi Muhammad" (Ahmed, 1992: 50).

Ibnu Rusyd (wafat tahun $1194 \mathrm{M}$ ) yang di barat dikenal sebagai Averrous, merupakan seorang filsuf muslim yang sangat baik memberikan penjelasan tentang Plato, Aristoteles, dan Al Farabi. Karya besarnya ialah Tahafut al Tahafut sebagai bantahan atas karya Al Ghazali berjudul Tahafut al Falasifah. Menurut Myers (2003: 58 - 61), karya Ibnu Rusyd tersebut lebih banyak menimbulkan reaksi di kalangan 
Yahudi dan Kristen ketimbang sebagai bantahan terhadap pemikiran Al Ghazali. Pemikiran Ibnu Rusyd mengenai keagamaan banyak mempengaruhi para pemikir yahudi dan Kristen.

Sumbangan peradaban Islam dalam aspek ilmu pengetahuan, terutama dalam ilmu Sains dan Filsafat, sangat besar. Sumbangan dalam ilmu Sains, mencakup: Fisika, Kimia, Farmasi, Kedokteran, Biologi, Astronomi dan Geografi. Kejayaan peradaban Islam dalam aspek ilmu pengetahuan yang sudah berkembang pada masa Khilafah Bani Abbasiyah disempurnakan oleh kekuasaan Islam di Andalusia (Spanyol) dari tahun 719 hingga jatuhnya Granada pada 1492 M (Muhzin, 2010: 8).

Peradaban Islam telah menjalankan peran penting sebagai agen perubahan peradaban Barat pada khususnya maupun peradaban umat manusia pada umumnya. Ilmu pengetahuan mengalir dan berpindah dari peradaban Islam menuju Eropa dan peradaban Barat adalah melalui kekuasaan Islam di Andalusia, Pulau Sisilia, dan Perang Salib. Sementara penyebaran filsafat dari Dunia Islam menuju Dunia Barat terjadi melalui jalur perdagangan, pendidikan, dan penerjemahan karya para filsuf muslim ke dalam bahasa Latin (Suyanta dalam Jurnal Ilmiah Islam Futura, Vol. X, No. 2, 2011: 26).

\section{SIMPULAN}

Berpijak dari pembahasan di atas dapat disimpulkan bahwa kejayaan peradaban Islam, terutama pada kurun waktu kekuasaan Bani Abbasiyah terjadi dalam masa pemerintahan Sultan Harun Al Rasyid dan Al Ma'mun. Kejayaan peradaban Islam tersebut dapat dicermati dari indikator atau pesrpektif ilmu pengetahuan. Elemen utama kejayaan peradaban Islam dalam perspektif ilmu pengetahuan adalah tingginya aktivitas ilmiah dan kemajuan ilmu pengetahuan baik ilmu keagamaan maupun ilmu pengetahuan umum. Tingginya aktivitas ilmiah ditandai dengan penyusunan buku-buku ilmiah dan gerakan penerjemahan. Kemajuan dalam ilmu keagamaan melahirkan berbagai disiplin seperti ilmu tafsir, ilmu hadits, ilmu kalam dan ilmu fikih. Sementara kemajuan dalam ilmu pengetahuan umum telah mengembangkan berbagai disiplin ilmu yang mencakup terutama filsafat, kedokteran, atronomi, matematika, dan geografi. Kemajuan ilmu pengetahuan umum dari masa kejayaan peradaban Islam ini dalam perkembangannya kemudian tersebar ke Eropa dan peradaban Barat melalui kekuasaan Islam di Andalusia, Pulau Sisilia dan terjadinya Perang Salib. Alhasil, sumbangan utama peradaban Islam bagi peradaban Barat dan Dunia adalah sebagai mata rantai yang telah mengembangkan ilmu pengetahuan warisan Yunani Kuno untuk dikembalikan lagi ke Eropa dan peradaban Barat. 


\section{DAFTAR PUSTAKA}

Ahmed, Akbar S. 1992. Citra Muslim Tinjauan Sejarah dan Sosiologi. Terjemahan Nunding Ram dan Ramli Yakub. Jakarta: Penerbit Erlangga.

Amin, M. Masyhur. 1995. Dinamika Islam (Sejarah Transformasi dan Kebangkitan). Yogyakarta: LKPSM.

Aslim, Faisal, 2014. "Peran Peradaban Islam dalam Perkembangan Ilmu Pengetahuan," dalam https://www.zenius.net, diakses tanggal 2 Januari 2019.

Belgrami, Hamid Hasan dan Sayid Ali Asyraf. 1989. Konsep Universitas Islam. Terjemahan Machnun Husein. Yogyakarta: Tiara Wacana.

Faqih, Aunur Rahim dan Munthoha (editor). 1998. Pemikiran dan Peradaban Islam. Yogyakarta: UII Press.

Mufrodi, Ali. 1997. Islam di Kawasan Kebudayaan Arab. Jakarta: Logos.

Mugiyono, 2013. "Perkembangan Pemikiran dan Peradaban Islam dalam Perspektif Sejarah," dalam Jurnal JIA, Vol. XIV, No. 1, Juni.

Muhzin Z., Mumun, 2010, "Warisan islam terhadap Perkembangan Ilmu dan Peradaban Dunia (Mengapresiasi Pemikiran Nurcholis majdid dan S.I. Poeradisastra)," Makalah disampaikan dalam Seminar Nasional yang diselenggarakan oleh DKM FISIP UNPAD tanggal 10 Desember.

Myers, Eugene A. 2003. Zaman Keemasan Islam Para Ilmuwan Muslim dan Pengaruhnya terhadap Dunia Barat. Terjemahan M. Maufur el-Khoiry. Yogyakarta: Fajar Pustaka Baru.

Nasution, Harun. 1985. Islam Ditinjau dari Berbagai Aspeknya. Jakarta: UI ress.

Suyanta, Sri, 2011. "Transformasi Intelektual islam ke Barat," dalam Jurnal Ilmiah Islam Futura, Vol. X, No. 2.

Watt, W. Montgomery. 1990. Kejayaan Islam Kajian Kritis dari Tokoh Orientalis. Terjemahan Hartono Hadikusumo. Yogyakarta: Tiara Wacana. 